\title{
PERFORMANCE OF SCOTCH PINE RACES UNDER PRAIRIE CONDITIONS
}

\author{
By W. H. CRAM and C. G. E. BRACK ${ }^{1}$
}

The senior antbor, William Hugb Cram, was born at Morden, Manitoba, in 1913, graduated from University of Manitoba with B.S.A. (1939) in Horticulture and M.Sc. (1948) in statistics and plant breeding, and from University of Minnesota with Ph.D. (1951) in plant breeding and genetics. For the period 1934.38 be was employed at the Dominion Experimental Station, Morden, as laborer and later Student Asst. in the Pomology (fruit breeding) section. He became supervisor of vegetable trials and laboratory demonstrator in borticulture at the University of Manitoba (1939-41), and Tree Planting Supervisor for the Forest Nursery Station, Indian Head, Sask., (1941-42). Dr. Cram was overseas with the R.C.A.F. in 1942-45. He became borticulturist al the Experimental Farm, Indian Head 1945.47 and from 1947 to the present, plant breeder at the Forest Nursery Station, Indian Head.

Charles George Edward Brack was born at Earl Grey, Sask. 1919. He allended the local school, and was employed as laborer on the agricultural farms 1933-41. He served with the Canadian army overseas during 1941-45. On bis return be was employed as laborer at Forest Nursery Station Indian Head 1945-49. As plotman, he has been assistant in the plant breeding work since 1949.

\section{ABSTRACT}

A study was made of the vigor and seed crops of trees comprising six geograpbic races of PINUS SYLVESTRIS L. The Scottish race exbibited superior vigor and the Russian race highesi survival after 41 years of growth, wbile the Rigensis race proved the most consistent producer of cones in the 1947 to 1952 period. The seeds-per-cone, seed-weight and seed-viability values varied greatly from year to year for individual trees of all races. Thus it would appear that selection of seed trees on the basis of seed characteristics alone bas little merit.

During the past decade an average of 38,000 plants of Scotch pine (Pinas sylvestris L.) have been distributed annually to farmers in the three prairie provinces of Canada by the Indian Head Forest Nursery Station for shelterbelt purposes. The adaptability of this species for planting in prairie farm shelterbelts has been well demonstrated. Munns and Stockeler (5) reported Scotch pine to rank second only to Jack pine for survival and growth in the Great Plains shelterbelts in the United States. At the Indian Head Forest Nursery Station, Scotch pine has been reported to be surpassed in vigor only by White spruce and Siberian larch (6). In addition, this species has

\footnotetext{
1 Plant Breeder and Plotsman, respectively, Forest Nursery Station, Indian Head, Sask.
} 
exhibited marked superiority to other pine species, not only for dependability of the seed crop, but also for seed-bed and transplant performances.

In 1947 an improvement program was initiated to "select superior seed trees from six geographic races of Scotch pine, as determined by their openpollination seed and seedlings."

\section{MAterial AND METHODS}

Seed trees under investigation were planted during the period 1908 to 1924 at a spacing of $4 \times 4$ feet in adjacent plots of 100 trees. Plants for these plots were produced locally from seed, which was labelled as being imported from Germany, Riga (i.e. Latvia), Scotland, Russia, Aberdeen (i.e., northern Scotland) and Finland. It was impossible to verify the exact source of these seed collections; as a result the designated origins have been assumed to comprise a geographic race for this paper.

In the evaluation of the individual seed trees the following data were secured: (1) seed-bearing capacity, in terms of seeds-per-cone from the annual harvest of a minimum of 25 cones from all bearing trees; (2) seed viability, which was based on the germination capacity manifested in the seed-beds 30 days after sowing; (3) seed-bed performance, which was a record of the seedlings surviving in the seed-beds the year following germination; (4) transplant survival of progenies planted as $2 / 0$ seedlings; (5) vigor and adaptability of progenies when line out in permanent plots as $2 / 2$ plants. This article presents information which has been accumulated since 1947 on the first three phases.

The 1948 seed-crop was utilized to providle a comparative picture of the seed and seedling characteristics for seed trees of the six geographic races. Sufficient seed was available from 108 seed trees for a large scale investigation of seed viability. In order to complete the quadruple lattice design adopted for the seed-bed germination study, it was necessary to include 1948 seed from 13 seed trees outside the six geographic races. Seven of these 13 seed trees were outstanding specimens in a 1906 plantation containing trees of French origin. The remaining 6 were outstanding seed trees in two large plantations planted in 1908 and 1910 with home-grown seedlings of unknown origin.

Nursery practices being followed on the station were adopted as far as possible. Seed was extracted by solar heat and sown dry the following spring. Seed-beds were treated with formaldehyde prior to sowing of the seed to reduce losses due to damping-off diseases. The seed was sown at a depth of one-half inch in rows (plots) of 100 seed each. Seed-beds were shaded with lath covers following sowing, and were watered as required via an overhead sprinkling system.

The Indian Head Forest Nursery Station is situated in the middle of the Canadian prairies $\left(50^{\circ} 31^{\prime}\right.$ N., $103^{\circ} 41^{\prime}$ W.) with an altitude of 1936 feet. The total annual precipitation averages 17 inches, and the frost-free period ranges firom 74 to 143 days. 


\section{RESULTS}

The present status of each plot, as presented in Table 1, might be assumed to represent the relative adaptability of the respective races. In 1949 the number of trees per plot ranged from 20 for the German race to 79 for the Finnish race. In the absence of records on the thinning practices followed, it has been assumed that the removals were due to death, thinning out trees with deformaties, or thinning out weaklings. Survival of Finnish seed trees (79\%) was almost twice that of the Aberdeen (43\%), while survival of Russian seed trees was considerably higher than the Rigensis or Scottish seed trees, the latter being more or less equal at $25 \%$ and $26 \%$ respectively.

Vigor of seed trees presented a somewhat different picture of the geographic races than survival data. Extreme ranges for height and diameter growth were manifested by the seed trees within most races. It was thought that direct comparisons of the height and diameter data for the various races were hardly valid due to the differences in ages. Hence, use was also made of a weighted measure of relative vigor, which was estimated by the formula:

$$
\frac{\text { mean height } \times \text { mean diameter }}{\text { age of seed trees }}=\mathrm{V} \text {. }
$$

The marked superiority of the Scottish race for height, diameter and relative vigor was evident. Although having the advantage of five years of growth, the German race barely equalled the Scottish race in vigor. The Finnish and Aberdeen races exhibited more or less equal vigor, although the greater competition between seed trees of the Finnish race may have been a limiting factor. On the other hand, the Russian race demonstrated greater vigor than the Rigensis race.

These results, although based on very small samples incapable of precise comparisons, seem to suggest that survival and growth are distinct characters of the various geographic races. It would appear that the Russian race exhibited the best combination (relative vigor $\mathrm{x}$ survival) of these two characters under prairie conditions. Nevertheless the high survival of Finnish seed trees and the superior vigor of Scottish seed trees indicate high degrees of regional compatibility for these races as well. On the other hand, the German, Rigensis and Aberdeen races manifested inferior adaptability.

Seed-bearing capacity of seed trees in the six geographic races of Scotch pine during the 1947 to 1952 period have also been summarized in Table 1. Complete data were not available for all seed-years because the entire 1951 seedcrop was lost to squirrels, while the 1949 and 1950 seed-crops were distorted due to a spring frost in 1949. In addition, it is possible that differences in ages, and competition, may have modified the reproductive processes of the seed trees within the various races. However, from the limited information available, it would appear that seed trees of the Rigensis race are the most consistent and reliable producers of cones under prairie conditions. The other 
races in declining order of their productivity were: Aberdeen, Finnish, Scottish, Russian and German.

Inferiority of 1949 and 1950 as seed-years may be attributed to the occurrence of a spring frost in 1949. A temperature of $22^{\circ} \mathrm{F}$. was recorded on May 23, 1949. This frost coincided with the anthesis stage of the 1949 flowers (for the 1950 cones), and with the initial enlargement of the embryonic cones (one-year-old cones developed from flowers pollinated in 1948) of Scotch pine. If the seed crop data presented in Table 1 provide a valid criterion, it would appear that both stages of the reproductive processes of Scotch pine were vulnerable to frost damage. Absence of more than 25 cones on seed trees of the Aberdeen race in 1949 may have been due to the

TABLE 1.

Survival, Vigor and Productivity of Seed Trees within 6 Grographic RaCES OF Pinus sylvestris (originally 100 plants per plot)

\begin{tabular}{|c|c|c|c|c|c|c|}
\hline \multirow[b]{2}{*}{ Character } & & \multicolumn{3}{|c|}{ Geograpbic Races } \\
\hline & Germ. & Riga. & Scot. & Russ. & Aber. & Finn. \\
\hline Year planted & 1908 & 1913 & 1913 & 1913 & 1924 & 1924 \\
\hline Survival \% in 1949 & 20 & 25 & 26 & 40 & 43 & 79 \\
\hline $\begin{array}{l}\text { Height in } 1949:- \\
\text { range (ft.) } \ldots \ldots . . . \\
\text { mean (ft.) }\end{array}$ & $\begin{array}{l}31-46 \\
39.8 \pm 1.1\end{array}$ & $\begin{array}{c}24-39 \\
28.4 \pm 0.8\end{array}$ & $\begin{array}{c}30-49 \\
39.5 \pm 0.9\end{array}$ & $\begin{array}{c}25-42 \\
34.9 \pm 0.7\end{array}$ & $\begin{array}{c}18-33 \\
25.3 \pm 0.7\end{array}$ & $\begin{array}{c}19-29 \\
25.0 \pm 0.3\end{array}$ \\
\hline $\begin{array}{l}\text { D.B.H. in } 1949:- \\
\text { range (in.) …... } \\
\text { mean (in.) } \ldots \ldots . .\end{array}$ & $\begin{array}{c}4.6-9.2 \\
6.8 \pm 0.3\end{array}$ & $\begin{array}{l}2.6-8.4 \\
4.8 \pm 0.3\end{array}$ & $\begin{array}{c}4.6-9.5 \\
6.3 \pm 0.3\end{array}$ & $\begin{array}{c}3.1-7.7 \\
5.3 \pm 0.2\end{array}$ & $\begin{array}{l}1.5-5.9 \\
3.4 \pm 0.2\end{array}$ & $\begin{array}{l}2.5-5.0 \\
3.2 \pm 0.1\end{array}$ \\
\hline Relative vigor (V)* & * 6.6 & 3.8 & 6.9 & 5.1 & 3.4 & 3.2 \\
\hline \multicolumn{7}{|l|}{$\begin{array}{l}\text { Trees with more than } \\
25 \text { cones in:- }\end{array}$} \\
\hline $1947(\%)$ & $?$ & 20 & 31 & 35 & 53 & 58 \\
\hline $1948(\%)$ & 60 & 44 & 69 & 45 & 63 & 58 \\
\hline $1949(\%)+\ldots$ & 15 & 44 & 19 & 12 & 0 & 15 \\
\hline $1950(\%) \ldots \ldots$ & 0 & 36 & 0 & 2 & 21 & 0 \\
\hline $1951(\%) \pm \ldots$ & $?$ & $?$ & $?$ & $?$ & $?$ & $?$ \\
\hline $1952(\%) \ldots \ldots$ & 0 & 16 & 15 & 10 & 12 & 5 \\
\hline Average $(\%)$ & 18.7 & 32.0 & 26.9 & 21.0 & 29.8 & 27.1 \\
\hline
\end{tabular}


freezing of embryonic cones. Similarly, destruction of the 1949 flowers by the same frost could explain the absence of a seed-crop on seed trees of the German, Scottish and Finnish races in 1950. If so, then it seems likely that some of the Rigensis and Russian seed trees may have exhibited frost-tolerance for both stages of the reproductive process, unless they were merely escapes. Further information is required to clarify the frost-reproduction interaction for all races of Scotch pine.

Browning of needles as a result of winter injury was manifested by most seed trees of Scotch pine in the spring of 1951. The degree of browning appeared to vary according to geographic race as follows: (1) Scottish and Russian seed trees exhibited no injury; (2) all Aberdeen and German seed trees showed slight injury; (3) seed trees of the Finnish race varied from severe for two to none for 77 trees; (4) Rigensis seed trees varied from light to severe with two showing no injury. Although the needles were cast by severely injured trees, complete recovery was achieved by all other trees by the fall of 1951.

Comparative data, on seed and seedling characteristics for seed trees of the six geographic races of Scotch pine, were provided by the 1948 seed-crop. Seed-crops from 108 of the total of 250 seed trees were involved. However, the inclusion of 13 seed trees outside the six races being studied ( 7 of French origin and 6 of unknown origin) was necessary to round out the statistical design used. The seed and seedling characteristics of the 121 seed trees have been summarized in Table 2.

Seed yield data in Table 2 would indicate that Scotch pine under prairie conditions may be expected to yield an average of 17.7 seeds-per-cone following solar extraction. Variations within races suggest differences between seed trees in cone size. For example, seed yield of seed trees in the Scottish race ranged from 8 to 46 seeds-per-cone. This may be a potential measure of regional adaptability. Average weight of seed from the 121 seed trees was 6.5 gramsper-thousand $(69,780$ to 103,000 seeds/pound). Very low seed viability ( $10 \%$ to $18 \%$ germination) was observed for some seed trees of Finnish, Russian and Scottish origin. This low viability may be attributable to seed dormancy, as dormancy of Scotch pine seed has been reported (4) for some seed trees at the extreme northern range. The existence of a mild seed dormancy was suggested for Pinus sylvestris by the low average germination capacity of 52.2 per cent for the 121 seed trees.

The number of one-year-old (1/0) seedlings produced from the 121 seed trees was found to represent from $8 \%$ to $73 \%$ of the seed sown for an average of 38.2 per cent. The seed-bed survival was from $48 \%$ to $97 \%$ of the germination. Conversely, average seed-bed losses due to disease, climate and other factors, amounted to 14 per cent of the seed sown or 27 per cent of the germination. No general relationship was found to exist between germination capacity of the seed (i.e. density of the seedlings) and seedling losses. Absence of the association may suggest the possibility that the seedling 
TABLE 2.

SuMMary OF Yield, SIzE AND VIABILITY OF THE 1948 SEED-Crop AND OF THE 1949-50 SEEd-BEd PERFormance OF THE SEEdlings From 121 Seed trees involving 7 Geographic Races of Pinus sylvestris

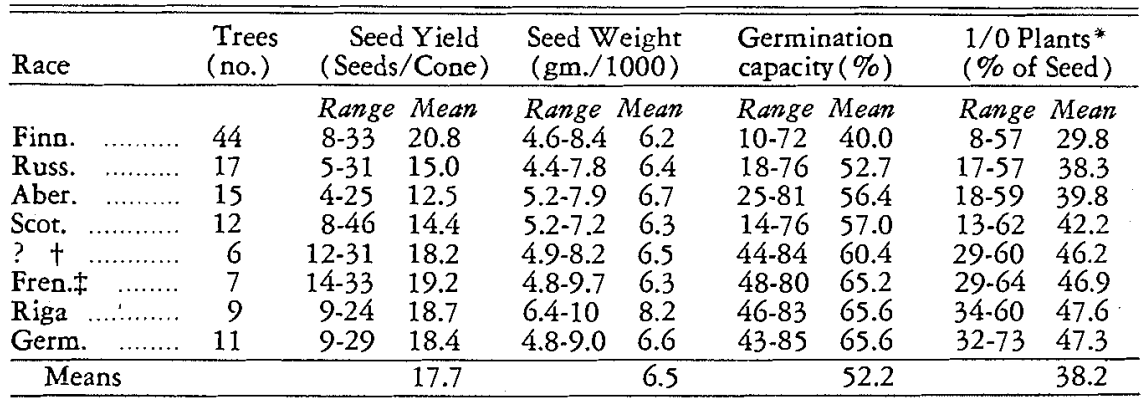

-1950 survival of 1949 germination in terms of \% of seed sown.

t-Selected secd trees of unknown origin planted in 1908 and 1910.

₹-Selected seed trees from al 1906 plantation of imported French seedlings.

TABLE 3.

SEED YIELd AND Viability FOR THE 1947-50 SEED-CROPS OF 12 SEED TREES OF Pinus sylvestris

\begin{tabular}{|c|c|c|c|c|c|c|c|c|c|c|c|c|c|}
\hline \multirow{2}{*}{\multicolumn{2}{|c|}{$\begin{array}{l}\text { Race \& } \\
\text { Seed tree }\end{array}$}} & \multicolumn{4}{|c|}{$\begin{array}{c}\text { Seed yieid } \\
\text { (seeds/cone) }\end{array}$} & \multicolumn{4}{|c|}{$\begin{array}{c}\text { Seed weight } \\
\text { (grams/1000) }\end{array}$} & \multicolumn{4}{|c|}{$\begin{array}{l}\text { Germination } \\
\text { capacity }(\%)\end{array}$} \\
\hline & & 1947 & '48 & 49 & 50 & 1947 & 48 & 49 & 50 & 1947 & '48 & 49 & '50 \\
\hline F-10 & $\ldots$ & .. 12 & 22 & 13 & - & 6.3 & 5.1 & 4.9 & - & 37 & 35 & 27 & - \\
\hline F-18 & & 7 & 17 & 11 & - & 8.0 & 6.5 & 7.2 & - & 68 & 42 & 49 & - \\
\hline F-52 & & 4 & 16 & 12 & 一 & 7.9 & 5.7 & 6.5 & - & 63 & 48 & 49 & - \\
\hline$F=90$ & & 9 & 24 & 15 & 一 & 5.1 & 3.9 & 4.5 & - & 42 & 47 & 58 & - \\
\hline A.7 & & 17 & 25 & - & 9 & 8.5 & 6.8 & - & 9.6 & 63 & 46 & - & 43 \\
\hline A- 45 & ........... & 11 & 5 & - & 12 & 8.9 & 6.5 & - & 9.9 & 51 & 34 & - & 27 \\
\hline A. 74 & & 7 & 6 & - & 14 & 8.5 & 7.4 & 一 & 8.5 & 40 & 25 & - & 37 \\
\hline A.99 & ............ & 18 & 4 & - & 16 & 8.1 & 6.6 & - & 9.1 & 59 & 67 & - & 57 \\
\hline R-698 & & 14 & 23 & 22 & 11 & 9.8 & 6.2 & 6.7 & 9.3 & 42 & 82 & 41 & 72 \\
\hline R-895 & ........... & 8 & 18 & 21 & 9 & 10.8 & 5.2 & 7.2 & 10.4 & $?$ & 48 & 70 & 80 \\
\hline S-291 & ........... & 1 & 8 & 3 & - & 8.5 & 4.9 & 6.7 & - & 58 & 67 & 39 & - \\
\hline Ru-191 & & 2 & 6 & 3 & 2 & 9.3 & 4.6 & 5.4 & 7.4 & $?$ & 66 & 50 & 75 \\
\hline Mear & ans & 9 & 14 & 12 & 10 & 8.3 & 5.8 & 6.1 & 9.2 & 52 & 50 & 48 & 56 \\
\hline
\end{tabular}

Absence of seed crops for the Aberdeen (A) seed trees in 1949 and for the Finnish (F) seed trees in 1950 attributed to spring frost in 1949 .

progenies differed in their reaction to seed-bed diseases and/or other causes of seed-bed losses. On the other hand, however, there was a strong relationship between germination and survival for seed trees of the Finnish, Scottish and German races. Thus, production of $1 / 0$ plants per 100 seed sown presents one practical means of comparing the relative productivity of seed trees. It was evident that at least one seed tree in each race was capable of producing sufficient $1 / 0$ seedlings to account for 57 per cent of the seed sown. 
The average performance of the respective races of Scotch pine under prairie conditions was suggested by the data in Table 2. Seed trees of the Finnish race apparently produced the greatest number of seeds-per-cone (20.8), and the smallest seed $(6.2 \mathrm{~g} . / 1000)$, with the lowest germination capacity. The Rigensis race was outstanding for large seed size (8.2g./1000), as well as demonstrating above average germination capacity and survival as one-yearold plants.

Records, which have been accumulated since 1947 for seed and seedling characteristics of 12 seed trees exhibiting the most consistent bearing habit, have been tabulated in Table 3. It was evident that the seeds-per-cone seed weight, and seed viability values for individual trees vary greatly from year to year. Apparently seed characteristics, although controlled by genetical factors, are modified from year to year by environment. Correlations between seed yield, seed weight and seed viability for the 1947-50 seed crops of the seed trees in the respective races were computed. No relationship existed between these seed characteristics for the Aberdeen and Scottish seed trees. However, seed weight and seeds-per-cone were found to be associated in a negative manner for the Finnish and Rigensis seed trees, while a similar though nonsignificant trend was suggested for the Russian seed tree. No other relationships approached a level of significance. In addition, no linear associations were evident in any races for the relationships of seed tree vigor and seed characteristics of the 1948 seed-crops. The results would indicate that selection for seed characteristics, alone, has little merit.

\section{DisCUSSION}

The survival and vigor of 6-year-old progenies from several races of Scotch pine were reported by Heimburger (3). The best strains (for Eastern Canada) appeared to be those from East Prussia, Latvia and Poland. Rudolf, after investigating the growth of 17-year-old seed trees of Scotch pine races in the Lake States area of United States, reported that the Riga race was best for growth combined with quality, and the Bohemian race was superior for rapid growth $(7,8)$. The limited information available from the present study suggests the relative survival and vigor of 25 - to 41-year-old seed trees of six geographic races of Scotch pine under prairie conditions. Greatest vigor was manifested by the Scottish race, followed by the German, Russian, and Rigensis races in order of declining vigor. More or less equal vigor was expressed by the 25-year-old Finnish and Aberdeen races. The Finnish and Russian races were outstanding from the standpoint of survival. These results, although based on very small samples which are incapable of precise comparison, seem to indicate that survival and growth are distinct characteristics. It would appear that the Russian race exhibited the best combination of these two characters under the rigorous prairie conditions. However, the high survival of Finnish seed trees (79\%) and the superior vigor of Scottish seed trees indicate high degree of regional adaptability for these races as well. On the other hand, the Rigensis race manifested only mediocre vigor and survival. 
It was evident that the seed and seedling characteristics reported in this study bore little agreement with the results obtained by other investigators of Scotch pine races. Natural hybridization between races may have occurred due to the close proximity of seed trees. Thus, the seed produced by any one seed tree may have been a heterozygous mixture resulting from intra- and inter-race pollinations. In addition, there is the possibility that the existing plots now contain the most adapted seed-trees of each of the respective races. No doubt a certain amount of natural selection took place in the local seedbeds prior to planting, while natural and artificial selection (i.e., thinning) have been in progress since the plots were planted. In addition the small samples of seed trees for each race left much to be desired.

Eliason (2) reported a range of 9 to 34 seeds-per-cone for Scotch pine following artificial extraction. In the present study the range was 4 to 46 seeds-per-cone when extracted by solar heat. Size of seed for a number of Scutch pine races has been reported by Rudolf (8) to range from 40,000 to 103,200 seeds-per-pound, with seed of the Riga race averaging 5.0 gramsper-1000. For the six geographic races involved in the present study, seed size ranged from 44,900 to 103,000 seeds-per-pound, while seed of Rigensis race averaged 8.2 grams-per-1000. Rudolf reported a germination range of $44 \%$ to $98 \%$ in 60 days, and $50 \%$ to $60 \%$ for the Riga strain. The germination capacity of seed from the six races in the present study ranged from $10 \%$ to $85 \%$ in 30 days, and $46 \%$ to $83 \%$ for the Rigensis race. Towmey and Stevens (9) reported a germination capacity of $23 \%$ to $87 \%$ for Scotch pine seed with a mean of 54.6 per cent. The mean germination capacity obtained for the 1948 seed crop of six geographic races was 52.2 per cent.

Dormancy of Scotch pine seed has been reported as being present for seed trees in the extreme northern parts of its range (4). The low viability (10\% to $18 \%$ ) manifested by seed from several seed trees of the Finnish and Russian races might be attributed to dormancy of such seed.

Low timber-yielding trees of Scotch pine have been found to frequently produce more abundant cones than high-yielding strains (1). Data to support this phenomenon were obtained. The Scottish and Russian races exhibited superior vigor to the Rigensis race, while the Rigensis race demonstrated the most consistent and abundant seed crops.

Seed size was conditioned by seed yield in a negative manner for some races. However, no relationship was found to exist between seed viability and seed size or seed yield. It would appear that seed characteristics of individual seed trees are modified from year to year by environment. Thus, selection on the basis of seed characters would appear to have little merit unless substantiated by performance data.

Finally it was evident that under prarie conditions some seed trees in each of the 6 races of Scotch pine were superior in vigor, seed yield, germination and seedling production. However, selection of the superior seed trees in each race will be governed by the results of progeny tests now in progress. 


\section{ACKNOWLEDGMENTS}

The authors wish to express appreciation to Mr. John Walker, Superintendent of the Forest Nursery Station, for his co-operation through the study. Acknowledgment is made to Dr. P. O. Rudolf, of the Lake States Forest Experiment Station, St. Paul, Minn., and to Dr. Mary MacArthur, Division of Horticulture, Ottawa, for their constructive criticisms of the manuscript.

\section{REFERENCES}

1. BALDWIN, H. I. Forst tree seed of the Northern temperate regions. Chronica Botanica Co., Waltham, Mass. 1942.

2. ELIASON, E. J. The size of Scotch pine cones as related to seed size and yield. Jour. For. $38: 65-66$. 1940 .

3. HEIMBURGER, C. C. On strain tests of Scots pine and Norway spruce. 1944. Annual Report, Internat. Union, For. Res. Organ. 1945.

4. Forest Service. Woody-plant seed manual. U.S.D.A. Miscel. Pub. No. 654. 1948.

5. MUNNS, E. N., and STOCKELER, J. H. How are the Great Plaing shelterbelts. Jour. For. $44: 237-257$. 1946 .

6. Progress Report, 1937-1946. Dominion Forest Nursery Stations, (Indian Head and Sutherland). Canada Dept. Agri. 1948.

7. RUDOLF, P. O. Variation in Scotch pine. Mich. Acad. Sci. 34:57-68, 1950.

8. RUDOLF, P. O. Scotch pine seed sources for Northern Minnesots. Proc. Minn. Acad. Sci. 16 :25-26. 1951.

9. TOWMEY. J. W., and STEVENS, C. L. The testing of coniferous tree seeds. Yale Univ. School of For. Bult. 21 . 1928 . 